\title{
How to '(not) Arrive': Hélène Cixous's and Sara Stridsberg's Drama vs. Appropriation
}

\author{
Romana Švachová
}

\begin{abstract}
In answer to Cara Berger, this article examines how Hélène Cixous's play Portrait de Dora and Sara Stridsberg's play Valerie ska bli president i Amerika approach as examples of feminist drama (and in case of Cixous, also an example of feminist postdramatic theatre) the problem of appropriation, an important question of feminist theories. The article maps the means the texts use to tackle the problem, or whether they resign on it, and discusses Cixous's reinstalment of the narrator in drama and usage of a structure based on the narrative mode of the stream of consciousness as methods to highlight appropriation processes.
\end{abstract}

\section{Keywords}

Hélène Cixous; Sara Stridsberg; feminist postdramatic theatre; appropriation; the narrator in drama; the stream of consciousness in drama 
In 2019, Cara Berger in the article 'Feminism in Posttraumatic Theatre: An Oblique Approach' asked: "What works do we consider as part of the spectrum of feminist theatre-making? What proper names, aesthetic forms and critical perspectives are summoned when we determine, debate and reforge connections between theatrical practices and feminist politics?" (Berger 2019: 423) Berger also suggested that there had been feminist postdramatic works, although not overtly, and in the article, she analysed the means of the so-called oblique approach. Her methodology war partially based on the theory of French poststructuralists Julia Kristeva and Hélène Cixous, thus also, via the latter, with the concept of écriture féminine, an experimental mode of writing connected prominently with the context of French second-wave feminism and deconstruction, a mode that aimed to create a subversive force in the literary sphere and by that, also in the sociocultural space. Although both Kristeva and Cixous focused in their theory mainly on literature, Berger suggested that there were certain crossroads of Lehmann's characteristic of postdramatic theatre and propositions made by Kristeva and Cixous; she pointed out that according to Lehmann, in postdramatic theatre there was a clear inclination to "abandon the representation of subjects in favour of embodiments of 'hidden impulses, energy dynamics and mechanics of [...] motorics'” (Berger 2019: 424), which, for sure, was also an important aspect of Cixous's and Kristeva's theories, as illustrated by their engagement and partial rework of Freuds and Lacan's psychoanalytic assumptions, leading Cixous to the formulation of "writing the body" method and Kristeva to her work on chora, the semiotic and the symbolic as linguistically disruptive forces and the possibilities these concepts offer to writing.

In this article, I intend to pick up on Berger's article and suggest some other answers to her initial questions presented above. To some extent, I will proceed analogously to Berger, who began with a re-examination of Pina Bausch's Café Müller, a piece from 1978, and then tried to identify analysed principles in a newer production, The Wooster Group's The Town Hall Affair that premiered in 2016. However, in one important aspect, I will digress from Berger's methodology, even though at first glance, it may seem counter-logical, given that postdramatic theatre does not, according to Lehmann, construct a mere stage reproduction of the initial script, but rather treats it as a semi-finished product that can be altered in many ways. Nevertheless, here I will not analyse a specific stage production; I will work solely with scripts of two plays, namely Portrait of Dora by Cixous herself (Portrait de Dora, written in 1976 for Théâtre du Soleil) and Sara Stridsberg's Valerie Jean Solanas for President of the United States (Valerie Jean Solanas ska bli president $i$ Amerika), stage-managed first time in 2006 by the Royal Dramatic Theatre in Stockholm. The main goal of this article is to analyse how the texts themselves approach and deal with the problem of appropriation, ${ }^{1}$ which is, as Berger rightfully stressed, central to Cixous and écriture féminine, because she rejects "phallocentrism and desire premised on appropriation" and instead, calls for "an act of approaching without appropriating,

1 On basis of Sarah Cooper's article regarding Cixous's novel Manne aux Mandelstams aux Mandelas, I defined here the problem of (general) appropriation as "the ethical wager for the writing self [consisting in the dilemma of] how to write about [other's] experience without making them her own” (Cooper 2000: 311). 
of 'not arriving' at a place of mastery while also not dismissing the other as completely remote and thus beyond our concern" (Berger 2019: 430).

The plays were chosen for several qualities that they share: for the first, both fall into the category of biographical fiction, a fact that promotes the problem of appropriation even more than in the case of a narrative proclaimed to offer pure fiction, however biographical or autobiographical it may covertly be; and interestingly, both the plays are highly intertextual, which also underscores the problem of appropriation, since the former encompasses selected parts of Freud's texts on his patient with the pseudonym Dora, given by him, whom he diagnosed with hysteria, and the latter emanates from the dramatic and literary work of the American radical feminist Valerie Solanas, the author of the satirical play Up Your Ass as well as the manifesto SCUM, from which one finds a sheer number of excerpts even in Stridsberg's take on Solanas' complicated life. Secondly, both the dramas approach controversial, marginalised female figures having been diagnosed with mental issues, but who refused the suggested treatment at a point ${ }^{2}$, or partially the diagnosis itself, and the diagnosis is indeed questioned today (for more, see Breanne Fahs' biography Valerie Solanas: The Defiant Life of the Woman Who Wrote SCUM (and Shot Andy Warhol), 2014); the texts then place these personalities and their point of view into the centre of attention in an empowering gesture, as well as contesting the "official" narratives surrounding them, by making them protagonists, which creates a certain platform for giving voice to those that were neglected by our culture; however, the voice is fictional in these cases, which, again, puts the problem of appropriation into light. And for the last, both the texts are playwriting debuts of the authors who prior to having written them, appeared on the literary scene and became connected with literary feminism, although in a different time and place; and above all, both the plays are stage adaptations of novels written by the authors themselves - in Cixous's case we are talking about the novel Portrait du soleil, in Stridsberg's about Drömfakulteten.

The fact that the plays are not only playwriting debuts, but also book adaptations, is, I believe, important as any other with regards to the purpose and methodology of this

2 "Nevertheless, although Freud never seems to have doubted Dora's version [of what happened with K by the lake], instead of displaying any sympathy for his vulnerable patient, he was to declare himself 'embarrassed' (Freud, p. 66) because her sharpness had no need of him to make sense of her situation, and to devote himself to proving, with extraordinary virtuosity, that [accepting K's version instead, denying any kind of harassment from his side] serve her own interest as well: that she really still loved K. The most obvious example of Freud's tunnel in his interpretation of a scene that had taken place when Dora was only fourteen. K, who was then approaching middle-age, had arranged to find himself alone with her, clasped her to him, and kissed her. Dora had torn herself away and fled. According to Freud, 'the reaction of this child of fourteen was already entirely hysterical' (Freud, p. 59); he goes on to propose that her various hysterical symptoms, such as her throat problems, were in reality displacements of the pleasure she had felt. Such manifest projection on Freud's part has occasioned all the more comment since the Dora case history was path-breaking in that it was the first to assert the importance of transference. Freud himself acknowledged that his own blindness was the reason the analysis failed, when Dora ended it only after three months. He attributed the failure to the fact that he had not realized that Dora was transferring the negative affect she felt for K onto him; only subsequently did he admit, though only in the margins of his text, in a footnote, that the main mistake consisted in his failing to realize the importance of Dora's homosexual love for Frau K. Freud considered this an intellectual failing on his part, not a symptom of his unconscious; it was Jacques Lacan who first pointed out the counter-transference at work in his analysis of Dora." (Hanrahan 1998: 49) 
article. Both authors later developed as dramatists and reflected upon the specificities of writing drama ${ }^{3}{ }^{4}$; my premise is that in their playwriting debuts and book adaptations at the same time, the boundary between a literary text and a dramatic text would be less clear and the genres would more overlap, which allows me to treat the texts also as literary ones.

\title{
Portrait of Dora: the narrator in drama
}

\begin{abstract}
"Cixous's choice of a theatrical form [for this work dealing with Dora's case] has received relatively little attention, her subversion of that form even less. The play was first staged by Simone Benmussa in 1976, and a version based on her production, and incorporating her stage directions, was then published. However, for the second edition, and again when the play was republished in 1986, Cixous chose to come back to her original text. The most significant difference between the two editions was that the 'Voice of the Play', which introduces and comments on the action in the original, had been replaced for the most part by 'Freud's Voice' in the Benmussa version." (Hanrahan 1998: 48)
\end{abstract}

The influence of Cixous's previous experience with writing novels, specifically with writing experimental literary texts trying to develop aesthetics and means that would correspond to aims of écriture féminine that the author described in the 1975 manifesto The Laugh of the Medusa (Le Rire de la Méduse) and later in her essays, show itself clearly in Portrait of Dora. The very first replica of the text in its original 1976 version belongs to the 'Voice of the Play', an unpersonified voice that proclaims the following over the scene:

VOICE OF THE PLAY “... These events declare themselves, like shadows, in dreams, they often become so clear that we feel we can reach out and grasp them, but, in spite of this, they elude any final clarification, and if we proceed without skill of particular caution, we find ourselves unable to determine whether or not such a scene ever really took place." (Cixous 2004: 35, italics in the original)

This is an important part of the exposition, and the only solid one here, given subsequent replicas of Dora and Freud, that, especially at this very beginning of the play,

3 "[Cixous] considers that the theatre is the space in which the writer and her writing are in the closest possible contact with the other, in all its forms. The immediacy of the theatre, in terms of time, creates writing that operates through a kind of 'violent condesantion' (p. 16). Cixous argues that writing for the theatre cannot indulge in long passages of reflection or diversion - pausing for an unspecified length of time here, wandering off in unknown directions here. On the contrary, she explains: 'One must lose neither time nor attention. No detours... The look of the spectator should go straight to the actor's heart' (p. 16). Cixous considers that the theatre is also an immediate physical space - a space in which one is brought into close proximity and made aware of the existence of many others." (Blyth - Sellers 2004: 54)

4 "Stridsberg betraktar själv pjäserna som annorlunda än romanerna. Tillkomma på ett annat sätt, under andra förutsättningar och i ett annat tempo. [...] Hon ser också uttrycket i pjästexterna som ett annat än det i romanerna. Om ingen är på plats för att plocka upp dem faller replikerna på det nakna scengolvet. [...] En pjästext är ingen litterär text, inte som en roman ett rum i vilket man kan vistas i långa tidsrymder och som förändras medan man vistas där. En pjästext är i första hand en samling anvisningar till regissör och skådespelare om hur scener och repliker skall tolkas. De är ett slags bruksanvisningar, kort sagt." (Sem-Sandberg 2012: 461-462) 
seem to have a clear surreal quality as they remind of a dream scene ${ }^{5}$. This initial replica of the Voice of the Play, which is, in fact, a quote of Freud himself ${ }^{6}$, specifically a loan from 'Notes upon a Case of Obsessional Neurosis', seems crucial because here, used in this manner in the very opening of the play, it does not remain simply a quote of Freud, not only because there is no acknowledgment of the source given in the play; by making specifically this quote an opening replica of the whole play, it is recontextualized to offer a comment both on the structure and the content of the play, as well as a disclaimer; in other words, it is turned into an exposition that is literally nothing more but a piece of factual information on what to expect: a dream of someone, a personal re-vision of the outplayed events. ${ }^{7}$ But who is the dreamer then? Especially if the Voice of the Play is quoting Sigmund Freud?

In the terms of literary theory, we could say the Voice of the Play has the role of overt narrator, who brings herself to light for specific purposes. As Maireád Hanrahan has pointed out, "Cixous's invention of the Voice of the Play is intricately bound with her concern to present a version of Dora's story that is different in genre (in both senses of the French word: genre and gender) from Freud's version" (Hanrahan 1998: 48). As for the difference Hanrahan addresses, it is established mainly by the self-reflectivity, the self-awareness of the play, created by the presence of the Voice of the Play and its disclaimers acknowledging the nature of the work on the overlapping borders of fact and fiction, dismissing the concept of any true objectivity by blending them; instead, by working on these borderlines, it warns us that there is always only bulk of subjective versions of events and that if one of the subjective versions is regarded as more valuable and becomes privileged over the others, or the others are completely disregarded as such, discrimination is created. In this case, we are thus informed that we are, indeed, about to see a subjective version of events as they were dreamt by the dreamer, the Voice of the Play, and by this, the Voice of Play indicates that we should approach the offered content as such.

5 "DORA [in a voice that shatter a silence - with a tone between a request and a threat] If you dare to kiss me,

I'll slap you! [With a cajoling reflection]

DORA [suddenly in his ear] Just dare to kiss me, I'll slap you!

FREUD Yes, you will tell me about it. In every detail.

DORA [in a faraway voice] "If you like." [in an awakened voice] If you wish. And then?

FREUD You will tell me about the scene by the lake, in every detail.” (Cixous 2004: 35)

6 Symptomatically, Ann Liddle's translation of Portrait de Dora does not use Alix and James Strachey's so-called Standard Edition translation of Freud's works into English. Instead, it offers a different translation, fully in concordance with the play's aim to provide a different version of the events. Feel free to compare Liddle's translation above with Strachey's translation and also, to take provided context into consideration: "In psycho-analyses we frequently come across occurrences of this kind, dating back to the earliest years of the patient's childhood, in which his infantile sexual activity appears to reach its climax and often comes to a catastrophic end owing to some misfortune or punishment. Such occurrences are apt to appear in a shadowy way in dreams. Often they will become so clear that the analyst thinks he has a firm hold of them, and will nevertheless evade any final elucidation; and unless he proceeds with the greatest skill and caution he may be compelled to leave it undecided whether the scene in question actually took place or not." (Freud 1981a: 206, text in bold highlighted by me)

7 This is typical for Cixous, who calls any story a dream in her poetically written theory (for more, see the chapter "The School of Dreams" in her collection of essays Three Steps on the Ladder of Writing). 
Later, the Voice of the Play makes another loan from Freud ${ }^{8}$ and proclaims one other replica in the first moments of the play - which script is symptomatically not structured into separated scenes or acts by nothing more than several indents between sections of replicas -, namely: "This initial account may be compared to an unnavigable stream, a stream whose bed is sometimes obstructed by rocks, sometimes divided by sandbanks" (Cixous 2004: 36, italics in the original). This time, the Voice of the Play informs us that the play will unfold in the manner of the stream of consciousness (but of whose consciousness then?), the modernistic mode which is known for its use of structure based on associations and focused on the fluidity of cognitive processes and that was, in fact, inspired by Freud's work on the unconscious, these very words included. And indeed, precisely these qualities can be attributed to Portrait of Dora as a whole. Dora's sessions with Freud serve here as a kind of a point of departure and an anchor at the same time, from which the narration constantly "travels" back to crucial points in Dora's or even Freud's memory or to Dora's dreams that she is requested by Freud to recount to him, and on at least two occasions, even to Freud's dreams. The discussed events or visions are more often shown on the stage than being simply retold in words, thus the sensory aspect of the events gets more prominence on the side of the spectator, and by that, understanding of a situation in favour of context and the sensorial instead of the spoken word could also be promoted. Both memories and dreams can start to outplay seemingly wildly, almost out of nowhere, being called out by associations, and sometimes, the difference between a dream showing the unconscious processes and using the symbolic vocabulary of dreams is indivisible from the dialogue of the patient and the therapist, who are also developing relations during the time:

DORA Mr K. was serious when he spoke to me I think.

FREUD Yes.

DORA But I didn't let him finish.

FREUD What were his actual words?

DORA I don't remember anymore. He said to me: you know that my wife means nothing to me. And I cut him off immediately.

MR K. You know that my wife means nothing to me.

$[\ldots]$

MR K. And I beg you to forgive me, and to say nothing about what happened.

DORA And what if I told you wife?

You offer me a cigarette. [...] Out of weariness, I agree to spend the night with you. You smoke two cigarettes. You have one in your mouth and one in your hand. You never stop talking.

This can't go on any longer. Besides, the cigarette is burning out.

FREUD [insinuating voice] Just one more puff!

8 "This first account [of the patient asked to give me the whole story of his life and illness] may be compared to an unnavigable river whose stream is at one moment choked by masses of rock and at another divided and lost among shallows and sandbanks." (Freud 1981b: 16 in Strachey's translation) 
DORA Well, let's hurry up and get it over with then!

FREUD [insinuating voice] And what if we went on a journey somewhere?

DORA I don't have the strength to start all over again. I accepted the cigarette out of weariness. But it's impossible for me to desire. I can no longer smoke or travel. Adieu, adieu! Where is the station?

FREUD Were those lilies-of-the-valley that were growing in big white patches next to the forest, just a kilometre or two away from your hand?

DORA And if the white flowers had been blue, would I have given up?

[Imitating her mother's voice] I am told: Shame on you! Dora, what are you doing? That's poison. It makes people stupid.

DORA Where! is! the! station! [She shouts]

VOICE OF THE PLAY What lilies-of-the-valley say in a dream

Mr K. said with a jewellery box.

What one says with flowers

Papa said with pearls

What Dora did not say

The Doctor said with smoke

DORA At last, at last, I arrive at the station.

MR K. There's no train. The rails have been cut.

$[\ldots]$

FREUD [in a normal voice] You knew there would be no train? No flowers for the forest; no train for the station [in your dream]. This is no accident. There is something you don't want to touch or catch. (Cixous 2004: 54-55)

As we can see in this highly dynamic scene in which Dora retells one of her dreams for Freud, between the plot of the dream and her dialogue with Freud about it, there is no clear boundary between the two plots indicated in the text. Thanks to that, Freud stepping into the shoes of Dora's past harasser Mr K. in the replicas "Just one more puff!" - smoking cigarette has here sexual subtext - and "And what if we went on a journey somewhere?" could be interpreted in more than one way, for example as: (1) a part of Dora's retold dream, displaying her transference; (2) Dora's vision happening during the session with Freud, displaying her transference; (3) an antimimetic portrayal of Freud seen through the Voice of the Play's eyes, showing him developing counter-transference to his patient, as suggested by Jacques Lacan after rereading 'Fragment of an Analysis of a Case of Hysteria' (Hanrahan 1998: 49).

The use of a structure resembling the literary stream of consciousness works in the play as another tool to promote the role of the narrator. Simply put, where there is a stream of consciousness, there must be also someone producing it; someone who, as shown in the example above, brings ambivalence in the case of this play, not clarification.

For modern realistic drama as presented by Ibsen, for example, the narrator is an abandoned, relic concept that one does not need to have in a play; instead, the stage itself and the analytic exposition are put to work to show and uncover everything that is needed for a delivery of a coherent message from the author himself. However, in 
line with tendencies of postdramatic theatre, to deliver a coherent, unified, thus ostensibly objective message is not the purpose of Portrait of Dora. The purpose is reversed here, because the concept of objectivity is problematized by the play, and therefore, the narrator, who nowadays is at home solely in the literature, is re-invited even onto the stage. Although the identity of the narrator remains here a mystery (it is not clear, for example, whether she is an extradiegetic or intradiegetic narrator, and if the latter, what character is it; is it Freud? Dora? somebody else? Cixous as the narrator? an anonymous narrator, a mere framework? the identity of the narrator is purposefully left to remain an implicit question), via coupling the Voice of the Play with the stream of consciousness Cixous created a subjectified point of view through which the events are shown, but without actual personification of the narrator. In other words, she pointed out that even in a genre that has rid itself of her, there is a narrator and by this, she implied that there is a narrator behind every story, every message, every communicated content, however objective account it seems to offer at first glance.

This emphasis serves more purposes at once: not only does it naturally question Freud's account of Dora's story by stressing that he is also a personal narrator of 'Fragments of an Analysis of a Case of Hysteria', but it is also an efficient way how to deal with the problem of appropriation. If narrative art (which drama is as well) stands trial for its fundamental principles - simply put, somebody is telling a story about someone else, even in the case if they are telling a story about themselves because in such a case, they construe themselves as characters in the story -, one of the logical solutions seems to be to acknowledge this circumstance and make it a part of both the content and the form of the work.

In postmodernist literature, metafiction and overt narrators that can be easily used for such acknowledgment have already become relatively common phenomena; on the stage, however, the use of it can be still seen as rarer, and thus experimental. Nevertheless, if we consider specifically feminist theatre-making, the questions the problem of appropriation proposes should be considered crucial in the same way as they are crucial to feminist literature, and for the very same reasons, if when considering appropriation a symptom of hegemony.

\section{Valerie Jean Solanas for President of the United States: the stage as memory space}

Interestingly, even though I have already described that at least in the case of the two plays discussed here, Sara Stridsberg, a major contemporary Swedish belletrist and dramatist, can be coupled with Cixous for her use of the same vastly intertextual recipe to create a biographical fiction about an actual person connected via history with feminism, who had experience with psychological (mis)care, Stridsberg herself has rejected the notion that she might have been influenced by Cixous ${ }^{9}$. However, not only the topical but also the formal similarities of Valerie Jean Solanas for President of the United States to Portrait of

9 “Croyez-vous à l'écriture de femme ? / - Non ! Je sais qu'ici, en France, vous êtes très influencé par Hélène Cixous et son concept d'«écriture féminine » mais je ne partage pas cette idée de la littérature. La seule 
Dora are considerable. A surrealistic conception of time, space and plot has also a significant role in the aforementioned Stridsberg's play; also here we find realistically depicted point of departure, namely the death bed in which Stridsberg's Valerie Solanas lays with severe pneumonia, but shortly afterwards, the bed is gone when anything in the hotel room brings out an old memory and in a subsequent scene, the plot jumps to the point in the protagonist's past that has been recalled. In other cases, such as in scenes 4,5 , and 17 , the room in which Valerie is dying becomes occupied by visions of clearly absent mother Dorothy Solanas or Cosmo Girl (Ann Duncan), an already gone lover, and the protagonist talks with both. The other characters that visit the patient during these last days of hers, namely Sister White and Daddy's Girl, might also be hallucinations of the lonely protagonist troubled by high temperatures, since these characters are not denoted as fully personified characters with proper names, but are given names that remind of something Valerie would call them if she was to belittle them (which she, at least with Daddy's Girl, does) and we do not get to know much of them; by this, they are constructed rather as walking stereotypes than proper characters. As a result, the stage is turned into a sort of Valerie's memory space that is ruled by similar laws and principles as the stage in Portrait of Dora; however, even this summarizing description of the play's form already indicates considerable differences in how the surrealistic conception of the time, space and plot works in the two texts.

In the case of the script to Valerie Jean Solanas for President of the United States, there is no reference that would indicate the presence of some narrator. It seems paradoxical if one knows that the play is in fact a stage adaptation of a novel by Stridsberg herself, The Faculty of Dreams (Drömfakulteten, 2005). The famous and critically acclaimed novel was written as a second-person narrative, in which we find means of metafiction, namely a character named "the Narrator" ("Berättaren" in Swedish) having occasional talks with the bedridden protagonist; the Narrator is probably female, but otherwise, we do not get to know much of her as a character, and thus, she can be viewed both as a supporting (and sort of elusive) character in the story and a narrative tool that was made overt by getting a body, but still presents rather an abstract concept since all other aspects of her identity remain a mystery. Similarly as the narrator of Portrait of Dora, even the Narrator of The Dream Faculty could be anyone. Moreover, the nonlinear plot depicting selected points from Valerie Solanas' life is several times interrupted by sequences that remind of writing notes or prose poetry focused on the mood and atmosphere, that are, in fact, central to the whole narrative.

In Valerie Jean Solanas for President of the United States, most of the quotes of the Narrator are turned into replicas of Daddy's Girl. However, even though I have mentioned that from the script, we do not get to know much of Daddy's Girl and Sister White (in comparison to other supporting characters of the play, e. g. Cosmo Girl or Andy Warhol), they are not tabula rasa; in the script, we find information that Daddy's Girl is a postgraduate student that is writing her dissertation on Valerie (Stridsberg 2012: 450) - not a novel or a piece of drama - and through their dialogue, we even get other pieces with Stridsberg in the French literary magazine Transfuge) 
of information about her, mostly leading to stereotyping her as a "dutiful daughter of patriarchy". In other words, Daddy's Girl and the Narrator of The Faculty of Dreams are hardly the same, although Daddy's Girl is given words of the latter, because in the play, she gets only the function of a supporting character, whereas in the novel, the Narrator can be considered as having more functions at once and by that, being an ambiguity.

With Portrait of Dora, I have also discussed the method of the stream of consciousness used as a guiding principle for the structure of the play. As indicated above, elements of such structure can be found in Valerie Jean Solanas for President of the United States as well; however, when compared to the former, the play is at first glance much more organized according to the principles of linear and logical narration. Here we get separated scenes (27) and although the drama as a whole does not comply with the principle of classical unities, the individual scenes do. One of the outcomes of such structure is that unlike in Portrait of Dora, the past (presented via memories) cannot dissolve into the presence of the protagonist. Thus, one of the possibilities for greater ambivalence, so greater interpretational freedom on the side of the recipient, is out of reach.

As the result, even though Valerie Jean Solanas for President of the United States has similar surrealistic quality as Portrait of Dora, it does not use it to approach and cope with the problem of appropriation. In the play, the life of Valerie Solanas is appropriated, as is the life of Sigmund Freud and his patient known under the pseudonym Dora in Portrait of Dora. However, Portrait of Dora acknowledges this fact via its reintroduction of the narrator to the stage and its work with a chaotic structure based heavily on the stream of consciousness, which supports the concept of the overt narrator and further develops it. In Valerie Jean Solanas for President of the United States, comparable structure from its novelistic predecessor was not transferred into the stage adaptation and as the result, the drama itself does not deal with the problem of appropriation, although it would be well suited especially with regards to its genre as well as topic.

\section{Turning back to the beginning}

One of the possibilities of how to manifest, and by that in fact dismantle appropriation even in Valerie Jean Solanas for President of the United States was, however, offered by Berger in her article. When analysing The Wooster Group's production of The Town Hall Affair, "a meditation on D. A. Pennebaker's documentary Town Bloody Hall (1971) featuring a fierce debate between Norman Mailer and a panel of feminists" (Berger 2019: 431), she described how the production used screening of parts of the original document, and on one key occasion, it used it next to a stage version of it performed by an actor in parallel. Thus, the "dance critic, essayist and lesbian feminist 'jokester' Jill Johnston" (Berger 2019: 434), who presented a poem at the panel discussion, was shown twice at this moment (that in the documentary was interrupted and cut short by Mailer) on the stage, once on the screen as Jill Johnston herself and once in the portrayal of her, performed by the actress Kate Valk. Berger remarks that "[Valk's] mimicking Johnston's physical and vocal characteristics is both foregrounded and complicated by 
the presence of the video which encourages spectators to assess her performance against the historical document" (Berger 2019: 434); in other words, by creating this contrast, the production used the original document for various reasons and indeed, one of them seems to be the need of dealing with the problem of appropriation. By showing and underlining the discrepancies between the original and the recreation, we get another kind of acknowledgement of the nature of the situation, this time created with the help of authentic multimedia.

When staging Valerie Jean Solanas for President of the United States, one could, in fact, choose to do the same: there is a plethora of video and audio material with Solanas in person. Besides several recorded interviews with her, there is also the short film I a man created by Warhol, in which, according to the biographer Breanne Fahs and even Stridsberg, she plays nobody but herself (Fahs 2014: 98; Stridsberg 2012: 433), and other records made by him when having talks with Solanas. However, the script of Stridsberg's play does not suggest this; instead, it proposes to recreate one of such recorded talks between the two artists during the performance on the stage without providing reference to the factual visual or audio material (scene 12, scene 19) and to outplay another one short film by Warhol, Blowjob. In this piece, however, Solanas does not perform.

When returning to Berger's questions presented at the beginning of this article, it is clear that to answer them fully, one would need to consider extensively more than this article could encompass. However, my intent was: (1) to suggest that if we are looking specifically for feminist postdramatic theatre, it might be useful to turn attention also to Cixous as a dramatist, not only as a literary theoretician; (2) the work of Sara Stridsberg, a feminist author and a major figure of contemporary Swedish drama, is also noteworthy when we are asking for "proper names, aesthetic forms and critical perspectives [... and] when we determine, debate and reforge connections between theatrical practices and feminist politics" (Berger 2019: 423); (3) the problem of appropriation, either cultural or any other, a challenge that narrative art is today facing on several fronts, was to some degree addressed already during the second-wave feminism and some means how to deal with the problem evolved in this area.

\section{Sources}

Berger, Cara (2019): 'Feminism in Postdramatic Theatre: An Oblique Approach'. In: Contemporary Theatre Review, 29/4, pp. 423-438.

Blyth, Ian - Sellers, Susan (2004): Hélène Cixous: Live Theory. New York/London: Continuum.

Cixous, Hélène (1993): Three Steps on the Ladder of Writing. New York: Columbia University Press.

Cixous, Hélène (1995): Le Rire de la Meduse. New York: Columbia University Press.

Cixous, Hélène (2004): 'Portrait of Dora'. In: Prenowitz, Eric (ed.). Selected Plays of Hélène Cixous. London/New York: Routledge, pp. 33-59.

Cixous, Hélène (2010): La Rire de la Méduse et autres ironies. Paris: Editions Galilée.

Cooper, Sarah (2000). 'The Ethics of Rewriting the Loss of Exile in «Manne aux Mandelstams aux Mandelas»'. In: Paragraph, 23/3, pp. 311-323. 
Desroziers, Marianne (not dated): 'Valérie Solanas: «Souvenez-vous que je suis la seule femme ici qui ne soit pas folle»'. Editions de l'Abat-Jour [online, quoted 10-5-2021]. Available from: http://www.editionsdelabatjour.com/pages/Valerie_Solanas_Souvenezvous_que_je_suis_la_ seule_femme_ici_qui_ne_soit_pas_folle_-4098732.html

Fahs, Braenne (2014): Valerie Solanas: The Defiant Life of the Woman Who Wrote SCUM (and Shot Andy Warhol. New York: The Feminist Press at CUNY.

Freud, Sigmund (1981a): 'Notes upon a Case of Obsessional Neurosis'. In: The Standard Edition of the Complete Psychological Works of Sigmund Freud X (1909): Two Case Histories (,Little Hans' and the ,Rat Man'). London: Vintage, pp. 155-318.

Freud, Sigmund (1981b): 'Fragment of an Analysis of a Case of Hysteria'. In: The Standard Edition of the Complete Psychological Works of Sigmund Freud VII (1901-1905): A Case of Hysteria, Three Essays on Sexuality and Others Works. London: Vintage, pp. 7-123.

Hanrahan, Maireád (1998): 'Cixous's Portrait de Dora: The Play of Whose Voice?'. In: The Modern Language Review, 93/1, pp. 48-58.

Lehmann, Hans-Thies (2006): Postdramatic Theatre. London/New York: Routledge.

Sem-Sandberg, Steve (2012): 'Medealand. (... Moderkartan, hemlandet, det övergivna, bortglömda, flyktningens dagdröm...)'. In: Stridsberg, Sara: Medealand och andra pjäser. Stockholm Albert Bonniers Förlag, pp. 455-463.

Stridsberg, Sara (2006): Drömfakulteten. Stockholm: Albert Bonniers Förlag.

Stridsberg, Sara (2012): 'Valerie Jean Solanas ska bli president i Amerika'. In: Stridsberg, Sara Medealand och andra pjäser. Stockholm Albert Bonniers Förlag, pp. 307-451.

Mgr. Romana Švachová / svachova@phil.muni.cz

Masarykova univerzita, Filozofická fakulta, Ústav germanistiky, nordistiky a nederlandistiky Arna Nováka 1, 60200 Brno, CZ 